\title{
Evaluation of Wound healing and Antiinflammatory Activities of New Poly-herbal Formulations
}

K. SOUJANYA, K. SRINIVAS REDDY, D. KUMARASWAMY, G. VISHWANATH REDDY, P. GIRIJAAND K. SIRISHA* 
Departments of Pharmacology and Medicinal Chemistry, Vaagdevi College of Pharmacy, Kishanpura, Hanamkonda, Warangal, Telangana-506 001, India

\section{Soujanya et al.: Herbal Formulations for Wounds and Inflammation}

Present investigation evaluated the impact of poly-herbal formulations comprising extracts of Zingiberofficinale, Curcuma longa, Aloe barbadensis, Citrus aurantium, Emblica officinalis and castor oil on wound healing activity using excision wound model and antiinflammatory activity using formalininduced pawedema method. Ointments containing 2, 4 and $6 \% \mathrm{w} / \mathrm{w}$ of extracts were made and used in wound healing action and all the formulations significantly $(p<0.01)$ reduced the wound area. Ointment of $6 \% \mathrm{w} / \mathrm{w}$ has shown better results than 2 and $4 \% \mathrm{w} / \mathrm{w}$. These results were compared to that of the standard framycetin. Poly-herbal formulation-1, poly-herbal formulation-2 and poly-herbal formulation-3 were prepared and used at doses of 100,300 and $500 \mathrm{mg} / \mathrm{kg}$ to determine antiinflammatory activity. All poly-herbal formulations significantly $(\mathbf{p}<\mathbf{0 . 0 1})$ inhibited formalin-induced rat paw edema. Poly-herbal formulation-3 displayed greater inhibition than poly-herbal formulations 1 and 2 . These results were comparable to that of the standard diclofenac. Present work and previous studies on poly-herbal formulations corroborates that these are safer and effective in treating inflammation and wounds.

Key words: Poly-herbal formulations (PHF's), wound healing, antiinflammatory activity, ointments, diclofenac, framycetin

Skin is the largest connective tissue in human body, which protects the body from external environment, maintains fluid homeostasis, responds to sensory stimuli and possesses self-healing ability. It is composed of highly cellular epidermis below which is the collagen rich extra cellular matrix known as dermis ${ }^{[1,2]}$. Wounds are injuries breaking the skin. Wound may cause loss of integrity as well as impair skin function to various extent ranging from severe disability to even death ${ }^{[3,4]}$. Conditions that may cause wounds include mechanical trauma, surgical procedure, decreased vascularization or aging. Wound healing is a cascade process, which involves many steps to repair the damaged tissue. It plays a vital role in preventing entry of foreign pathogen into the host and to restore the injured tissue to normal. Wound healing is classified into various phases; it begins with inflammation followed by tissue build up, granulation phase, scar remodeling and closure of the wound ${ }^{[5-7]}$.

Since many decades mankind has been using plants to treat wounds, which accelerate wound healing through various mechanisms. The main advantage of the phytochemicals that are present in plants is that they are affordable. Wound healing property of phytochemicals has grabbed attention of many researchers ${ }^{[8]}$. Intense research is going on to identify the active constituents and mode of action of phytochemicals ${ }^{[9]}$. The medicinal value of plants can be attributed to the phytochemical constituents that affect physiology of human body ${ }^{[10]}$. Various plant constituents include phenolic compounds,

*Address for correspondence

E-mail: ragisirisha@yahoo.com saponins, steroids, terpenoids, alkaloids, essential oils, flavonoids and tannins ${ }^{[11]}$.

Non-steroidal antiinflammatory drugs (NSAIDS), the most commonly used prescription drugs to treat inflammation exert their action by inhibiting both the enzymes, cyclooxygenase 1 and 2 (COX-1 and COX-2). Various NSAIDS inhibit COX enzymes to varying degrees ${ }^{[12]}$. Inhibition of COX enzymes results in decreased production of leukotrienes and prostaglandins. Decreased production of prostaglandins may affect the permeability of the endothelial cells whereas under production of hyaluronic acid results in decreased wound healing process ${ }^{[13,14]}$. NSAIDS also hinder the synthesis of thromboxane A2 resulting in decreased platelets aggregation thus increasing the chance of hematoma. Studies have shown that inhibition of thromboxane A2 delays the process of wound healing by interrupting angiogenesis ${ }^{[15,16]}$.

In view of the above documented complications of NSAIDS, phytochemicals are regarded as better alternatives to treat inflammation. In this work, efforts were made to corroborate the efficacy of phytochemicals extracted from ginger (Zingeber officinale), turmeric (Curcuma longa), amla (Emblica

\footnotetext{
This is an open access article distributed under the terms of the Creative Commons Attribution-NonCommercial-ShareAlike 3.0 License, which allows others to remix, tweak, and build upon the work non-commercially, as long as the author is credited and the new creations are licensed under the identical terms
}

Accepted 24 December 2019

Revised 07 October 2019

Received 11 July 2019

Indian J Pharm Sci 2020;82(1):173-178 
officinalis), bitter orange (Citrus aurantium), aloe vera (Aloe barbadensis) and castor oil (Ricinus communis) in treating wounds and inflammation.

The plant materials, ginger and turmeric rhizomes, amla fruits, peels of bitter orange, leaves of aloe vera and castor oil were purchased from the local market and authenticated in the Department of Botany, Kakatiya University, Warangal, India. Extracts were prepared adopting the procedures mentioned in earlier reported work ${ }^{[17]}$ to study the wound healing and antiinflammatory activities. Ethanol, Polyethylene glycol (PEG) 4000, PEG 600, diclofenac, carboxymethylcellulose (CMC), double distilled water, framycetin sulphate ointment were used in the present study.

After obtaining permission from the Institutional Animals Ethics Committee (Application no: 2012/11/1/ S-II/5), for the animal study protocols, Wistar rats were procured from Sainaath Laboratories, Uppal, Hyderabad. Rats of either sex weighing 150-200 g were selected, maintained at $24-28^{\circ}$, housed individually with free access to food and water. They were fed with standard diet and kept in a well-ventilated animal house with alternate dark-light cycle of $12 \mathrm{~h}$ throughout the studies.

The extracts were mixed with alcohol and water (1:1) and screened for the presence of phytoconstituents using various chemical tests. Curcuma longa contained terpenoids and phenols. Zingiber officinale contained alkaloids, carbohydrates, proteins, amino acids, steroids, terpenoids, glycosides, flavonoids and phenols. Aloe vera contained saponins, proteins, amino acids, steroids, terpenoids, flavonoids and phenols. Citrus aurantium contained alkaloids, carbohydrates, steroids, terpenoids, glycosides, flavonoids, tannins and phenols. Emblica officinalis contained alkaloids, carbohydrates, saponins, steroids, terpenoids, glycosides, flavonoids, tannins and phenols.

After screening for phytochemicals, the next step was to formulate the polyherbal preparations. Three formulations were prepared to determine wound healing and antiinflammatory potential. An ointment with water soluble base was the first choice due to the ease of preparation and also the ease of cleaning after application. PEG ointment base with a mixture of PEG 4000 and PEG 600 in ratio 3:7 was found to have sufficient consistency, thus suitable for ointment preparation. Ointments were prepared with concentrations of $2 \%$ (test-1), $4 \%$ (test-2), $6 \%$ (test-3) $\mathrm{w} / \mathrm{w}$ of extracts. All the above formulations were prepared by fusion method. The prepared formulations were then evaluated for consistency and stability. Three formulations
TABLE 1: COMPOSITION OF POLYHERBAL FORMULATIONS I, II AND III

\begin{tabular}{lccc}
\hline \multirow{3}{*}{ Extracts } & \multicolumn{3}{c}{$\begin{array}{c}\text { \% concentration of extract used in } \\
\text { formulations }\end{array}$} \\
\cline { 2 - 4 } Aloe vera & PHF-I & PHF-II & PHF-III \\
Citrus aurantium & $1 \% \mathrm{w} / \mathrm{w}$ & $3 \% \mathrm{w} / \mathrm{w}$ & $3 \% \mathrm{w} / \mathrm{w}$ \\
Curcuma longa & $3 \% \mathrm{w} / \mathrm{w}$ & $1 \% \mathrm{w} / \mathrm{w}$ & $3 \% \mathrm{w} / \mathrm{w}$ \\
Emblica officinalis & $1 \% \mathrm{w} / \mathrm{w}$ & $3 \% \mathrm{w} / \mathrm{w}$ & $3 \% \mathrm{w} / \mathrm{w}$ \\
Zingiber officinalis & $3 \% \mathrm{w} / \mathrm{w}$ & $1 \% \mathrm{w} / \mathrm{w}$ & $3 \% \mathrm{w} / \mathrm{w}$ \\
Castor oil & $1 \% \mathrm{w} / \mathrm{w}$ & $3 \% \mathrm{w} / \mathrm{w}$ & $3 \% \mathrm{w} / \mathrm{w}$ \\
& $3 \% \mathrm{w} / \mathrm{w}$ & $1 \% \mathrm{w} / \mathrm{w}$ & $3 \% \mathrm{w} / \mathrm{w}$ \\
\hline
\end{tabular}

were prepared to determine antiinflammatory activity as shown in Table 1. Doses of poly-herbal formulations PHF-1, PHF-II and PHF-III were prepared in doubledistilled water containing $1 \% \mathrm{w} / \mathrm{v} \mathrm{CMC}$ as a solution and administered in respective doses.

Excision wound ${ }^{[18]}$ animals were secured to operation table and exposed to light ether anesthesia. A circular wound of about $314 \mathrm{~mm}^{2}$ was made on the sterilized dorsal thoracic region of each of the rat. The animals were divided into 5 groups of 6 rats each. The animals of group I and II served as control (untreated) and standard (treated with $1 \% \mathrm{w} / \mathrm{w}$ framycetin sulphate), respectively. Animals of group III, IV and V were treated with 2, 4 and $6 \% \mathrm{w} / \mathrm{w}$ poly herbal ointments respectively. The ointments are topically applied once a day, starting from the day of the operation till complete epithelialisation. The parameters studied were percent wound closure and epithelialisation time. The wounds were traced on $\mathrm{mm}^{2}$ graph paper on $\mathrm{d} 4,8$ and 12 and thereafter on alternate days until healing was complete. The percent wound closure was calculated. The epithelialisation period was calculated based on the days required to shed the wound's remnant dead tissue without any traces of raw wound. $\%$ closure $=$ $1-\mathrm{Ad} / \mathrm{Ao} \times 100$, where, Ao is the wound area on day zero $\left(314 \mathrm{~mm}^{2}\right)$, Ad is the wound area on corresponding days.

Formalin-induced rat paw edema ${ }^{[19,20]}$ model was developed in 11 groups of rats with 5 rats in each group, which were treated with vehicle, standard (diclofenac $20 \mathrm{mg} / \mathrm{kg}$ ) PHF-I, PHF-II and PHF-III (100, 300 and $500 \mathrm{mg} / \mathrm{kg}$, po), $1 \mathrm{~h}$ prior to formalin injection. About $0.05 \mathrm{ml}$ of $1 \% \mathrm{w} / \mathrm{v}$ solution of formalin was injected into the subplantar tissue of left hind paw of each rat. Inflammation of the injected foot injected was measured at hourly intervals from 0 to $4 \mathrm{~h}$ using a plethysmometer. About $0.1 \mathrm{ml}$ of vehicle was injected into the right hind paw of each animal. The reduction in paw volume is calculated as: $\%$ inhibition $=\mathrm{Vc}-\mathrm{Vt} \times 100 / \mathrm{Vc}$, where, $\mathrm{Vc}$ is the paw volume of control, $\mathrm{Vt}$ is the paw volume of 
test. Statistical analysis was performed using one way ANOVA followed by Dunnet's comparision test. The values are expressed as mean \pm standard error mean.

Phytochemical studies indicated the presence of various constituents as shown in Table 2. In all polyhedral formulations there was no considerable change in characters like colour, odour and consistency and there was no phase separation observed during the course of study. Also, no patches on rat skin were observed during skin irritant test. The scar area in control rats on $\mathrm{d} \mathrm{4,8}$ and 12 were found to be $247.83 \pm 4.79,174.33 \pm 2.73$ and $73 \pm 6.26 \mathrm{~mm}^{2}$, respectively. Similarly, framycetin-treated rats have shown respective scar areas of $135.66 \pm 3.38$, $81 \pm 2.36$ and $32.5 \pm 2.07 \mathrm{~mm}^{2}$ on $\mathrm{d} 4,8$ and 12. Scar areas after treatment of poly-herbal formulations $(2,4$ and $6 \% \mathrm{w} / \mathrm{w}$ as ointment) on $\mathrm{d} 12$ were $29 \pm 2,25 \pm 2.36$ and $8 \pm 2.82 \mathrm{~mm}^{2}$, respectively. Percent closure of scar area in control rats and framycetin-treated rats on the last day of study (i.e. d 12) were found to be 76.75 and $89.64 \%$, respectively (fig. 1). Epithelization times in control rats and framycetin-treated rats were found to be $20.33 \pm 0.74$ and $15.16 \pm 0.37$, respectively. The polyherbal formulations ( 2,4 and $6 \% \mathrm{w} / \mathrm{w}$ as ointment) have shown epithelization times of $14.66 \pm 0.47,13.66 \pm 0.74$ and $10.83 \pm 0.68$, respectively.

Acute inflammation induced by formalin resulted from cell damage, which triggers the production of endogenous mediators like histamine and bradykinin. Edema produced by formalin was significantly $\mathrm{p}<0.01)$ inhibited by PHFs $(100,300$ and $500 \mathrm{mg} / \mathrm{kg}$, po, Table 3). Thus, it could be concluded that PHFs possessed antiinflammatory activity, which could be mediated via inhibition of prostaglandin synthesis might have a potential benefit for the management of inflammatory disorders. PHF-III has shown significant antiinflammatory activity than PHF-I and PHF-II in comparison to diclofenac. The order of antiinflammatory activity of formulations were PHF-
III $>$ diclofenac $>$ PHF-II $>$ PHF-I.

The poly-herbal ointments (2, 4 and $6 \% \mathrm{w} / \mathrm{w})$ have exhibited significant wound healing activity on $\mathrm{d} 4,8$ and 12. There is a substantial decrease in scare area in rats (percent closure of scar area 90.76, 92.03 and $97.45 \%$ ) treated with 2,4 and $6 \%$ poly-herbal ointments when compared to rats treated with framycetin. Epithelization also improved considerably in polyherbal ointment treated rats than framycetin-treated rats. Wound healing and antiinflammatory activities could be due to the presence of flavonoids, phenols, amino acids, terpenoids and tannins in the formulations.

From these studies it was evidenced that polyherbal formulations have shown noticeable effect in accelerating wound healing in comparison to conventional allopathic treatment. Poly-herbal formulations containing extracts of rhizomes, curcuma, aloe vera have depicted improved wound healing in normal and diabetic rats ${ }^{[21]}$. Aloe vera was

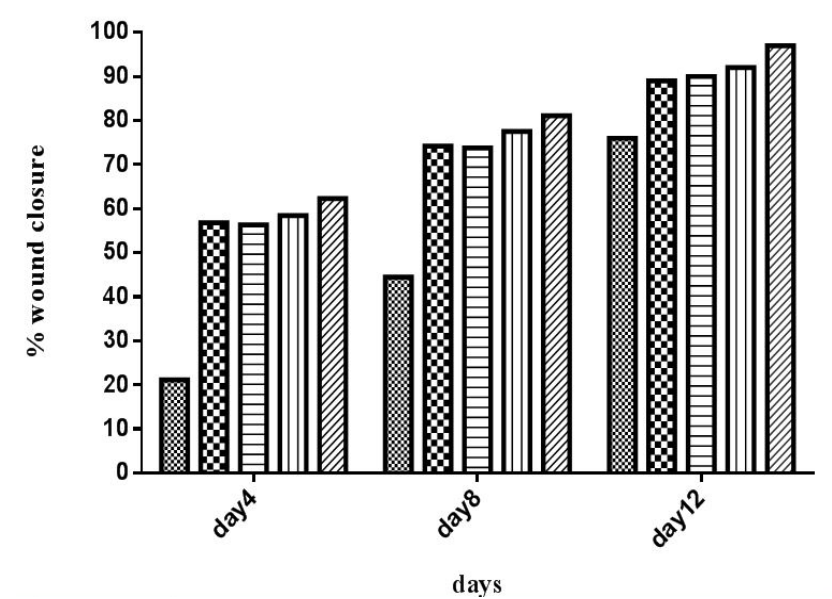

Fig. 1: \% wound healing by the poly-herbal formulations at 3 different doses on $\mathrm{d}, 8$ and 12

Data represents \% wound closure by the poly-herbal formulations at 3 different does on $\mathrm{d} 4,8$ and 12, (网) control, (Q) standard, (日) formulation I, (|||D) formulation II, (VA) formulation III

\section{TABLE 2: PHYTOCHEMICAL STUDIES OF VARIOUS EXTRACTS}

\begin{tabular}{|c|c|c|c|c|c|}
\hline Chemical class & Curcuma longa & Zingiber officinale & Aloe vera & Citrus aurantium & Emblica officinalis \\
\hline Alkaloids & - & - & - & + & + \\
\hline Carbohydrates & - & + & - & + & + \\
\hline Saponins & - & - & + & - & + \\
\hline Proteins & - & + & + & - & - \\
\hline Amino acids & - & + & + & - & - \\
\hline Steroids & - & + & + & + & + \\
\hline Terpenoids & + & + & + & + & + \\
\hline Glycosides & - & + & - & + & + \\
\hline Flavonoids & - & + & + & + & + \\
\hline Tannins & - & + & - & + & + \\
\hline Phenols & + & + & + & + & + \\
\hline
\end{tabular}

The symbols (+) means present, (-) means absent 


\begin{tabular}{|c|c|c|c|c|c|c|}
\hline \multirow{3}{*}{ Treatment $(\mathrm{mg} / \mathrm{kg})$} & \multicolumn{6}{|c|}{ Paw edema volume $(\mathrm{ml})$} \\
\hline & \multicolumn{6}{|c|}{ Time } \\
\hline & $0 \mathrm{~min}$ & $1 \mathrm{~h}$ & $2 \mathrm{~h}$ & $3 \mathrm{~h}$ & $4 \mathrm{~h}$ & $\%$ inhibition at $4 \mathrm{~h}$ \\
\hline Control & $0.68 \pm 0.06$ & $0.66 \pm 0.04$ & $0.6 \pm 0.05$ & $0.66 \pm 0.04$ & $0.6 \pm 0.05$ & - \\
\hline Standard (20) & $0.68 \pm 0.06$ & $0.43 \pm 0.11^{* *}$ & $0.26 \pm 0.07^{* *}$ & $0.15 \pm 0.07^{* *}$ & $0.04 \pm 0.01^{* *}$ & 93.16 \\
\hline PHF-I (100) & $0.66 \pm 0.07$ & $0.56 \pm 0.07$ & $0.41 \pm 0.06^{* *}$ & $0.3 \pm 0.08^{* *}$ & $0.21 \pm 0.06^{* *}$ & 64 \\
\hline PHF-I (300) & $0.7 \pm 0.08$ & $0.53 \pm 0.04$ & $0.36 \pm 0.07^{* *}$ & $0.26 \pm 0.07^{* *}$ & $0.18 \pm 0.06^{* *}$ & 69.50 \\
\hline PHF-I (500) & $0.6 \pm 0.07$ & $0.53 \pm 0.04^{* *}$ & $0.36 \pm 0.07^{* *}$ & $0.26 \pm 0.07^{* *}$ & $0.16 \pm 0.07^{* *}$ & 72.33 \\
\hline PHF-II (100) & $0.66 \pm 0.07$ & $0.5 \pm 0.08$ & $0.33 \pm 0.11^{* *}$ & $0.23 \pm 0.11^{* *}$ & $0.15 \pm 0.05^{* *}$ & 75 \\
\hline PHF-II (300) & $0.7 \pm 0.08$ & $0.43 \pm 0.07^{* *}$ & $0.31 \pm 0.06^{* *}$ & $0.2 \pm 0.08^{* *}$ & $0.09 \pm 0.05^{* *}$ & 84.83 \\
\hline PHF-II (500) & $0.66 \pm 0.07$ & $0.45 \pm 0.07^{* *}$ & $0.26 \pm 0.07^{* *}$ & $0.15 \pm 0.07^{* *}$ & $0.05 \pm 0.02^{* *}$ & 90.83 \\
\hline PHF-III (100) & $0.68 \pm 0.06$ & $0.5 \pm 0.08$ & $0.36 \pm 0.09^{* *}$ & $0.23 \pm 0.11^{* *}$ & $0.13 \pm 0.06^{* *}$ & 77.83 \\
\hline PHF-III (300) & $0.66 \pm 0.07$ & $0.46 \pm 0.07^{* *}$ & $0.33 \pm 0.07^{* *}$ & $0.16 \pm 0.04^{* *}$ & $0.08 \pm 0.02^{* *}$ & 86.16 \\
\hline PHF-III (500) & $0.66 \pm 0.07$ & $0.55 \pm 0.09^{* *}$ & $0.33 \pm 0.09^{* *}$ & $0.16 \pm 0.07^{* *}$ & $0.04 \pm 0.01^{* *}$ & 93.33 \\
\hline
\end{tabular}

Values expressed as mean $\pm S E M, n=5,{ }^{* *} p<0.01$ as compared with control using one way ANOVA followed by Dunnet test

reported to accelerate the process of wound healing by influencing various phases like inflammation, collagen synthesis and wound contraction ${ }^{[22]}$. Another study also corroborated that both oral and transdermal aloe vera was effective in wound healing ${ }^{[23]}$. Significant wound healing in rabbits was seen with curcuma longa and honey when compared to control ${ }^{[24]}$.

This work as well as previous studies on polyherbal formulations gave evidence that the polyherbal formulations are safe and effective in treating inflammation and wounds. It is advisable to conduct clinical studies to prove that these have better clinical utility compared to NSAIDS.

\section{Acknowledgements:}

Authors thank the Management, Principal and HOD (Pharmacology) of Vaagdevi College of Pharmacy, Hanamkonda, Telangana for providing the necessary facilities. They also thank Dr. V. S. Raju, Taxonomist, Department of Botany, Kakatiya University for authenticating the plant material.

\section{REFERENCES}

1. Proksch E. PH in nature, humans and skin. J Dermatology 2018;45(9):1044-52.

2. Kabashima K, Honda T, Ginhour F, Egawa G. The immunological anatomy of the skin. Nat Rev Immunol 2019;19:19-30.

3. Tsuruta D, Green KJ, Getsios S, Jones JC. The barrier function of skin: how to keep a tight lid on water loss. Trends Cell Biol 2002;12(8):355-7.

4. Ghosh K, Clark R. Principles of tissue engineering. In: Lanza R, Langer R and Vacanti J, editors. Wound Repair. II. Basic Biol Wound Repair. Cambridge, MA, USA: Academic Press; 2007.

5. Sami DG, Heiba HH, Abdellatif A. Wound healing models: A systematic review of animal and non-animal models. Wound Med 2019;24(1):8-17.

6. Ashrafi M, Baguneid M, Bayat A. The role of neuro mediators and innervation in cutaneous wound healing. Acta Derm
Venereol 2016;96(5):587-97.

7. Emmerson E. Efficient Healing Takes Some Nerve: Electrical Stimulation Enhances Innervation in Cutaneous Human Wounds. J Investig Dermatol 2017;137(3):543-5.

8. Ibrahim N, Wong SK, Mohamed IN, Mohamed N, Chin $\mathrm{KY}$, Ima-Nirwana $\mathrm{S}$, et al. Wound healing properties of selected natural products. Int $\mathrm{J}$ Environ Res Public Health 2018;15(11):2360.

9. Hwang JK, Kong TW, Baek NI, Pyun YR. $\alpha$-Glycosidase inhibitory activity of hexagalloylglucose from the galls of Quercus infectoria. Planta Med 2000;66(03):273-4.

10. Akinmoladun AC, Ibukun E, Afor E, Akinrinlola B, Onibon $\mathrm{T}$, Akinboboye A, et al. Chemical constituents and antioxidant activity of Alstonia boonei. Afr J Biotechnol 2007;6(10):212.

11. Edeoga H, Okwu D, Mbaebie B. Phytochemical constituents of some Nigerian medicinal plants. Afr J Biotechnol 2005;4(7):685-8.

12. Warner TD, Giuliano F, Vojnovic I, Bukasa A, Mitchell JA, Vane JR. Nonsteroid drug selectivities for cyclo-oxygenase-1 rather than cyclo-oxygenase-2 are associated with human gastrointestinal toxicity: a full in vitro analysis. Proc Natl Acad of Sci 1999;96(13):7563-8.

13. Murota S, Chang W, Abe M, Otsuka K. The stimulatory effect of prostaglandins on production of Hexosaminecontaining substances by cultured fibroblasts. Prostaglandins 1976;12(2):193-5.

14. Murota SI, Abe M, Otsuka K, Chang WC. Stimulative effect of prostaglandins on production of hexosaminecontaining substances by cultured fibroblasts (2) early effect of various prostaglandins at various doses. Prostaglandins 1977;13(4):711-7.

15. Jones MK, Wang H, Peskar BM, Levin E, Itani RM, Sarfeh $\mathrm{IJ}$, et al. Inhibition of angiogenesis by nonsteroidal antiinflammatory drugs: insight into mechanisms and implications for cancer growth and ulcer healing. Nat Med 1999;5(12):1418.

16. Lelcuk S, Klausner JM, Merhav A, Rozin RR. Prostacyclin (PGI2) and thromboxane (Tx) A2: mediators of wound healing. Isr J Med Sci 1987;23(7):841-3.

17. Sirisha $\mathrm{K}$, Soujanya $\mathrm{K}$, Mahendar $\mathrm{P}$, Begum $\mathrm{S}$. In vitro Antioxidant and Cytotoxic Activities of New Herbal Ointments. Indian J Pharm Educ Res 2016;50(2):S1-S10.

18. Rakesh MR, Rajkumar VS. Pharmacological investigation on the wound healing effect of castor oil in rats. Int J Univ Pharm Life Sci 2011;1:1-8. 
19. Sarkar D, Dutta A, Das M, Sarkar K, Mandal C, Chatterjee M. Effect of Aloe vera on nitric oxide production by macrophages during inflammation. Indian J Pharmacol 2005;4:23-26.

20. Miao L, Tao H, Peng Y, Wang S, Zhong Z, El-Seedi H, et al. The anti-inflammatory potential of Portulaca oleracea L.(purslane) extract by partial suppression on NF- $\mathrm{KB}$ and MAPK activation. Food Chem 2019;290:239-45.

21. Gupta A, Upadhyay NK, Sawhney RC, Kumar R. A polyherbal formulation accelerates normal and impaired diabetic wound healing. Wound Repair Regen 2008;16(6): 784-90.
22. Chithra P, Sajithlal GB, Chandrakasan G. Influence of aloe vera on the healing of dermal wounds in diabetic rats. J Ethnopharmacol 1998;59(3):195-201.

23. Chithra P, Sajithlal GB, Chandrakasan G. Influence of Aloe vera on the glycosaminoglycans in the matrix of healing dermal wounds in rats. J Ethnopharmacol 1998;59(3):179-86.

24. Kundu S, Biswas TK, Das P, Kumar S, De DK. Turmeric (Curcuma longa) rhizome paste and honey show similar wound healing potential: a preclinical study in rabbits. Int J Low Extrem Wounds 2005;4(4):205-13. 